\title{
RESEARCH ON MAGNETIC DECLINATION IN LITHUANIAN TERRITORY
}

\author{
Romuald Obuchovski, Petras Petroškevičius, Arūnas Būga \\ Institute of Geodesy of Vilnius Gediminas Technical University, \\ Sauletekio al. 11, 10223 Vilnius, Lithuania \\ E-mail: gi@ap.vgtu.lt
}

Received 08 May 2007, accepted 31 March 2008

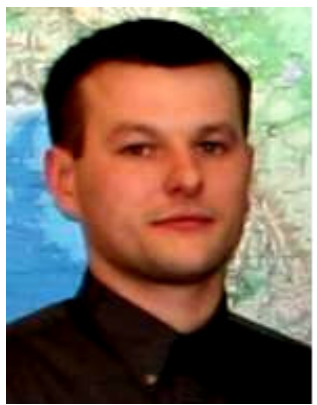

Romuald OBUCHOVSKI, Dr

Date and place of birth: Seinai, Poland, 1977.

Education: bachelor's degree in Geodesy, Vilnius Gediminas Technical University (VGTU) (2000); master of science in Measurement Engineering (2002); doctoral degree in Technological Sciences (2006).

Fields of research: Earth's magnetic field.

Present Position: research worker at Institute of Geodesy of VGTU, assistant at Geodesy and Cadastre Department at VGTU.

Publications: 11 scientific papers.

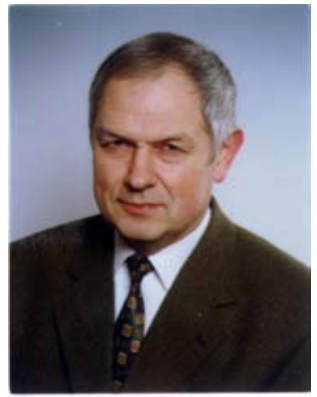

Petras PETROŠKEVIČIUS, Prof Dr Habil

Date and place of birth: Pušalotas, Lithuania, 1944.

Education: engineer of astronomic-geodesy, Moscow State University of Geodesy and Cartography (MIIGAiK) (1970); doctor of Technical Science (1978); Habil. Doctor of Technical Sciences, VGTU (2002).

Fields of research: determination of orbits of satellites around the Earth, research of Earth's gravity field by means of satellite geodesy and gravimetric methods, establishment of geodetic and gravimetric networks.

Present Position: director of Institute of Geodesy of VGTU, professor of Department of Geodesy and Cadastre.

Publications: more than 100 scientific papers. Monograph - Effect of Gravitational Field on Geodetic Observations, co-author of manual entitled Geodesy 2.

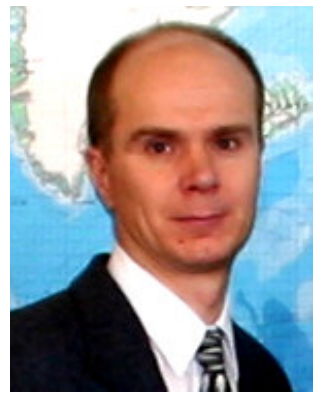

Arūnas BŪGA, $\mathrm{Mr}$

Date and place of birth:Vilnius, Lithuania, 1965.

Education: Vilnius Civil Engineering Institute, engineer surveyor (1988) VGTU, master of science (1991).

Fields of research: GPS, calibration of EDM instruments, establishment of geodetic networks.

Present Position: quality manager at Calibration Laboratory, Institute of Geodesy, VGTU; assistant at Geodesy and Cadastre Department at VGTU.

Publications: 14 scientific papers.

\begin{abstract}
Magnetic declination is the angle between the planes of the astronomic and magnetic meridians. Magnetic declination is used in navigation, geophysics, geodesy, cartography, geology, and other fields.

Magnetic declination is often computed from the World Magnetic Model (WMM). It is therefore important to be aware of the accuracy of the computed declination and to investigate its changes. For this purpose, magnetic declination was measured and the methodology of its measurement analyzed. Research was performed at six established points in 1999, 2001 and 2004. Magnetic declination was measured at Vilnius, Kaunas and Klaipèda airports in 2006
\end{abstract}


For magnetic declination measurements, the nonmagnetic Theo 010 B theodolite with Flux D/I magnetometer was used. Astronomical azimuth was determined according to the Sun's hourly angle. Possibilities of determining astronomical meridian were investigated. The influence of the point and Sun coordinates were estimated.

Based on this research, the Belsk Geomagnetic Observatory was selected as the most suitable one for the reduction of Lithuanian observation data. The registration at the Belsk observatory was used to compute annual mean values. The mean error of declination obtained was 0.3 '.

Based on research results, it was determined that declination values computed from the WMM magnetic model may have errors up to $1.5^{\circ}$. Annual variations in declination reached $7^{\prime}$.

Keywords: magnetic declination, astronomical azimuth, geomagnetic field model.

\section{Introduction}

The determination of the parameters of the Earth's geomagnetic field and research of their variation are actual and complex problems in natural science. This topic is related to our knowledge of the state of natural physical system outer parameters of present geophysical and geodynamical processes.

Data from geomagnetic field research helps solving different theoretical and practical tasks, like those in navigation, geophysics, geodynamics, and exploration for minerals. According to the requirements of NATO and the ICAO (International Civil Aviation Organization), the parameters of the geomagnetic field are presented on topographic maps and navigational charts. A compass or director is used in geodesy for orientation when an instrument arrow points along the lines of the geomagnetic field. In this case, information on geomagnetic declination is necessary to determine direction. Declination value and annual change in declination value are presented on topographical maps.

The aim of this investigation was to improve the method used to determine geomagnetic declination and its variation and to estimate the accuracy of the World Magnetic Model in Lithuania.

\section{Measurement of magnetic field at repeat stations}

Detailed and accurate information about magnetic field parameters and their secular variation can be obtained from the magnetic observatories continuously measuring the geomagnetic field $[4,1,2]$. Unfortunately, the global network of observatories provides magnetic data only at a limited number of unevenly distributed locations. Geomagnetic repeat station measurements complement the continuous recordings of observatories, providing a denser coverage of ground observations.

Six stations specially constructed for measurements of the geomagnetic field in Lithuania were established in 1999 [8]. The new Lithuanian repeat station network consists of six stations (Žiežmariai, Dusetos, Parovèja, Šaukotas, Tryškiai and Šyliai) that are evenly distributed throughout the country. Non-magnetic markers mark stations. The mean distance between the stations is approximately 150 kilometres. These stations are located at a sufficient distance from buildings, factories, and other anthropogenic sources of magnetic field disturbances. Locations of repeat stations are shown figure 1. Geomagnetic field parameters were observed by the VGTU Institute of Geodesy in collaboration with specialists from the Institute of Geodesy and Cartography in Warsaw in 1999, 2001 and 2004. The field parameters measured included declination, inclination, and total intensity. A nonmagnetic TheoO10B theodolite with Flux $D / I$ magnetometer was used for the measurements of declination and inclination, and a proton magnetometer PMP-05a was used for total intensity.

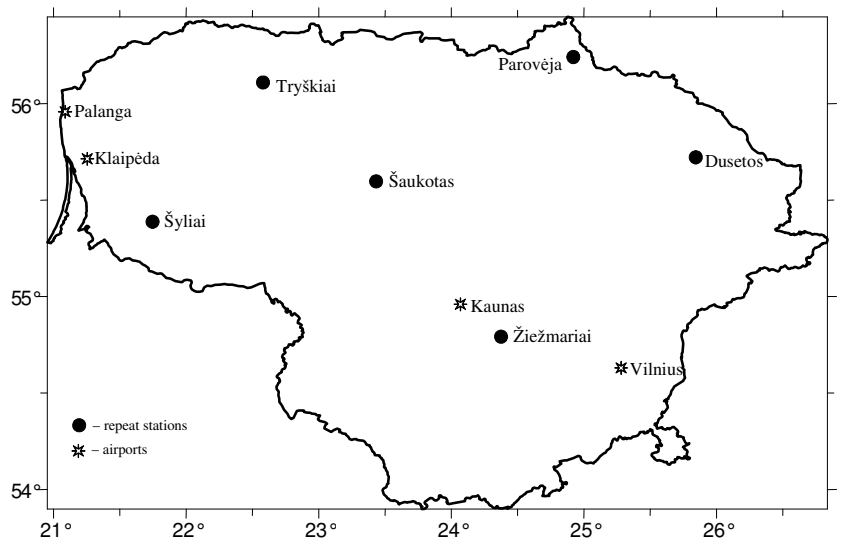

Fig 1. Locations of repeat stations and airports

In the course of the first campaign, two ground targets were selected at each station. The astronomical method of hour angle of the Sun observations for astronomical azimuth of ground targets determination was used. Astronomical azimuths were obtained from two independent series. These azimuths were also used to compute declination during two subsequent campaigns.

Ten series of magnetic declination measurements were conducted at each station. Each of these series consists of two independent sets. A set conducted as follows:

- observation of two reference marks (in the first position of the theodolite vertical circle),

- observations with $D / I$ (magnetic azimuth of the reference mark) (in both positions of the theodolite vertical circle),

- observations of the reference marks (in the second position of the theodolite vertical circle).

After these observations, preliminary results were calculated in order to be sure that no gross error had occurred. Then, the second set was performed.

A detailed topographic description of the station and the access to it was made. The geographical coordinates and elevation were determined using topographic maps and GPS. 


\section{Measurement of magnetic declination at airports}

Magnetic declination measurements at four airports (Vilnius, Kaunas, Klaipėda and Palanga) were performed in 2006. Locations of airports are shown in figure 1 . The nonmagnetic TheoO10B theodolite with Flux D/I magnetometer was used. Specially constructed stations were established at each airport approximately 50100 meters from the takeoff runway. Two reference marks for the determination of astronomical and magnetic azimuth were chosen. A Trimble 5000 total station was used to determine the station coordinates and astronomical azimuth of the chosen reference marks.

Three series of magnetic declination measurements were conducted at each airport. Each measurement series consisted of two independent sets. A set conducted in the same order as described above.

The series were separated by 15-20-minute breaks.

\section{Astronomical observations}

To determine magnetic declination, it is necessary to know the astronomical azimuth of ground objects, which is often determined according to observations of the Sun and the magnetic azimuth of the same object, which is by Flux D/I magnetometers. Compared to observations of stars, observations of the Sun provide the surveyor with a more convenient and economical method to determine accurate astronomic azimuth. Two methods are used to determine an azimuth by observing the Sun: the altitude method and the hour angle method. The basic difference between these two is that the altitude method requires an accurate vertical angle and approximate time, whereas the hour angle requires a very accurate time but no vertical angle. The hourly angle method is mostly used in magnetic measurements.

To apply the hour angle method, we measure the horizontal angle from a line to the Sun. Then, knowing the accurate time of observation and our position (latitude and longitude), we can compute the azimuth of the Sun by using this equation:

$$
\tan A_{N}=\frac{\sin t}{\sin \varphi \cos t-\cos \varphi \tan \delta},
$$

where $\varphi$ - latitude of the station; $t=s-\alpha-$ Sun hourly angle; $\delta$ and $\alpha$ - Sun's equatorial coordinates, declination, and right ascension; $s=T+u-$ local sidereal time; $T$ - readings of chronometer; and $u$ corrections of chronometer readings at Sun observation time.

The azimuth is then combined with the horizontal angle to yield the azimuth of the line.

The possibilities of determining the astronomic meridian were investigated [7]. To determine the astronomic meridian from the Sun's hour angle and to reduce the effect of errors, it is necessary to determine coefficient $K$ allowable values. Coefficient values express the velocity of the change in the Sun's azimuth.

$$
K=\frac{15 \cos \delta \cos q}{\sin z},
$$

where $\delta$-declination of the Sun, $q$-parallax angle, and $z$-zenith distance of the Sun.

The value of coefficient $K$ decreases, when the zenith distance of the Sun increases as well as by performing observations, when the Sun is closer to the horizon. $K$ decreases when the absolute value of the declination of the Sun increases. The variations in coefficient $K$ from sunrise to sunset at true Sun time $m$ 。 moments with different values of the Sun's declination are presented in figure 2 .

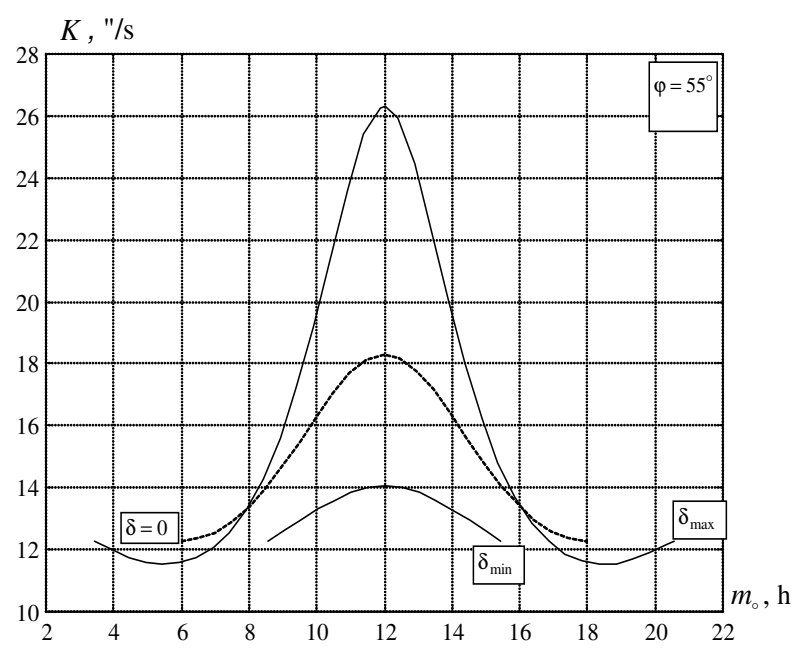

Fig 2. Daily variation of $K$ coefficient

It is clear from the graph that the curves of coefficient $K$ values are symmetric with regard to midday. Therefore, the best time to determine azimuth is in the morning or evening, when coefficient values are smaller and the zenith distance of the Sun is higher, but below $80^{\circ}$. Atmospheric fluctuations and the effect of sidelong refraction increase with a larger zenith distance. When the winter solstice is approaching, uninterrupted observations can be performed even during midday, but total time suitable for observations increases as the summer solstice approaches. Selecting symmetric positions of the Sun to meridian for observations can reduce the influences of latitude and errors in the Sun's declination.

\section{Data reduction and results}

The first results of a regional magnetic survey are magnetic field values measured at stations on different days in one year or in several years. Such values are not directly comparable and cannot be used to produce any charts because of variations in the geomagnetic field [5]. The method suggested by Institute of Geodesy and Cartography in Warsaw for data reduction was used for observations. This method has been analyzed and research on the reduction of the geomagnetic field parameter possibilities has been performed. 
The computation of final annual mean values at the repeat stations was done according to equation [5]:

$$
D\left(x_{i}, t_{\text {ann }}\right)=\frac{\sum_{k=1}^{n}\left(D\left(x_{i}, t_{k}\right)-D\left(O, t_{k}\right)\right.}{n}+D\left(O, t_{a n n}\right)
$$

where $D\left(x_{i}, t_{a n n}\right)$ is the mean annual value of geomagnetic declination at location $x_{i}$ (repeat station or point at airport), $D\left(x_{i}, t_{k}\right)$ is the value of geomagnetic declination $D$ at same $x_{i}$ place at observation time $t_{k}$, $D\left(O, t_{k}\right)$ is the value of the declination at observatory $O$ at the same observation time $t_{k}$, and $D\left(O_{i}, t_{a n n}\right)$ is the mean annual value of declination at the reference observatory.

Equation (3) is based on the assumption that all geomagnetic variations, both external and secular variation, are the same at the observatory and the station. These reduction errors depend on the distance between the station and the observatory, the electrical conductivity beneath the two locations, and the secular variation gradient. It is therefore very important to select the observatory in the correct way. Research of geomagnetic observatories' suitability for reduction of geomagnetic observation data was performed. Data measured in 1999 and 2001 was reduced, as references observatories in Hel, Lovo, Nurmijarvi and Belsk were used. Values of $D$ determined in series at repeat stations and differences in series between stations and observatories were computed. RMS errors of differences were computed and their evaluation proved that Belsk Geomagnetic Observatory was the best suited for reduction.

Data from all observation cycles at repeat stations in Lithuania and data from observations at airports were reduced using the Belsk geomagnetic observatory as a reference point. Programmes developed at the Institute of Geodesy and Cartography of Poland was used for data processing. Data were reduced to 1999.5, 2001.5 and 2004.5 epochs [3].

Geomagnetic declination values from these epochs at Lithuanian repeat stations are presented in table 1 . The changes in mean annual declination, $\delta D$, between epochs were calculated.

The result of measurements at repeat stations shows that every five years geomagnetic declination rises approximately linearly at all the repeat stations. Declination values vary from $4.5^{\circ}$ to $6.5^{\circ}$. Mean annual change in declination ranges from $5.8^{\prime}$ to $6.6^{\prime}$.

Table 1. Mean annual values and changes of geomagnetic declination

\begin{tabular}{|c|c|c|c|c|c|}
\hline \multirow{2}{*}{ Repeat station } & \multirow{2}{*}{$\begin{array}{c}D_{1999.5} \\
\mathrm{o}\end{array}$} & \multirow{2}{*}{$\begin{array}{c}D_{2001.5} \\
\mathrm{o}\end{array}$} & \multirow{2}{*}{$\begin{array}{c}D_{2004.5} \\
\mathrm{o}\end{array}$} & & \multicolumn{2}{|c|}{$\delta D$} \\
\cline { 5 - 6 } & & & & $\delta D_{1999.5-2001.5}$ & $\delta D_{2001.5-2004.5}$ \\
& & & +5 \\
\hline Žiežmariai & 55755 & 60932 & 62654 & +548 & +547 \\
\hline Dusetos & 53927 & 55022 & 60737 & +527 & +545 \\
\hline Parovėja & 53129 & 54245 & 60105 & +538 & +607 \\
\hline Saukotas & 40451 & 41604 & 43514 & +536 & +623 \\
\hline Tryškiai & 45748 & 50909 & 52901 & +540 & +637 \\
\hline Šyliai & 42417 & 43616 & 45554 & +459 & +633 \\
\hline
\end{tabular}

\section{Errors in the world magnetic model}

The world magnetic model (WMM) is often used to calculate declination values at airports. The accuracy of the WMM in Lithuania was examined. Errors in the WMM were determined by using two methods: firstly, by comparing declination values computed from the model with those obtained at the repeat stations and airports, and secondly, by comparing model values with those of an updated map from the 1940.5 epoch [6]. Model errors at the repeat stations were up to $1^{\circ}$. Differences between the WMM and the declination map by K. Sleževičius updated to the 2000.5 epoch are illustrated in figure 3 . The Sleževičius map was created by measurements at 179 points [9].

The errors of the model within most of Lithuania reach $1.5^{\circ}$ as seen from figure 3 , yet in the northeast of the country, they reach $4^{\circ}$. The errors of the model at the repeat stations and airports are shown in table 2.
Table 2. Differences between declination values calculated from WMM and measured ones

\begin{tabular}{|c|c|c|c|c|c|}
\hline \multicolumn{2}{|r|}{ Points } & $\begin{array}{c}\Delta D_{1999.5} \\
\text { o } 1.5\end{array}$ & $\Delta D_{2001.5}$ & $\begin{array}{c}\Delta D_{2004.5} \\
\mathbf{0},\end{array}$ & $\begin{array}{c}\Delta D_{2006.5} \\
\mathbf{0}\end{array}$ \\
\hline \multirow{6}{*}{ 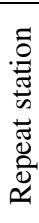 } & Žiežmariai & +110 & +057 & +116 & \\
\hline & Dusetos & +009 & +002 & +020 & \\
\hline & Parovèja & +013 & +007 & +024 & \\
\hline & Šaukotas & -037 & -050 & -028 & \\
\hline & Tryškiai & +028 & +015 & +037 & \\
\hline & Šyliai & +018 & +006 & +026 & \\
\hline \multirow{4}{*}{ 总 } & Vilnius & & & & +007 \\
\hline & Kaunas & & & & +034 \\
\hline & Klaipèda & & & & -112 \\
\hline & Palanga & & & & -153 \\
\hline
\end{tabular}

According to the results, the declination error calculated from the model may reach up to $2^{\circ}$. 


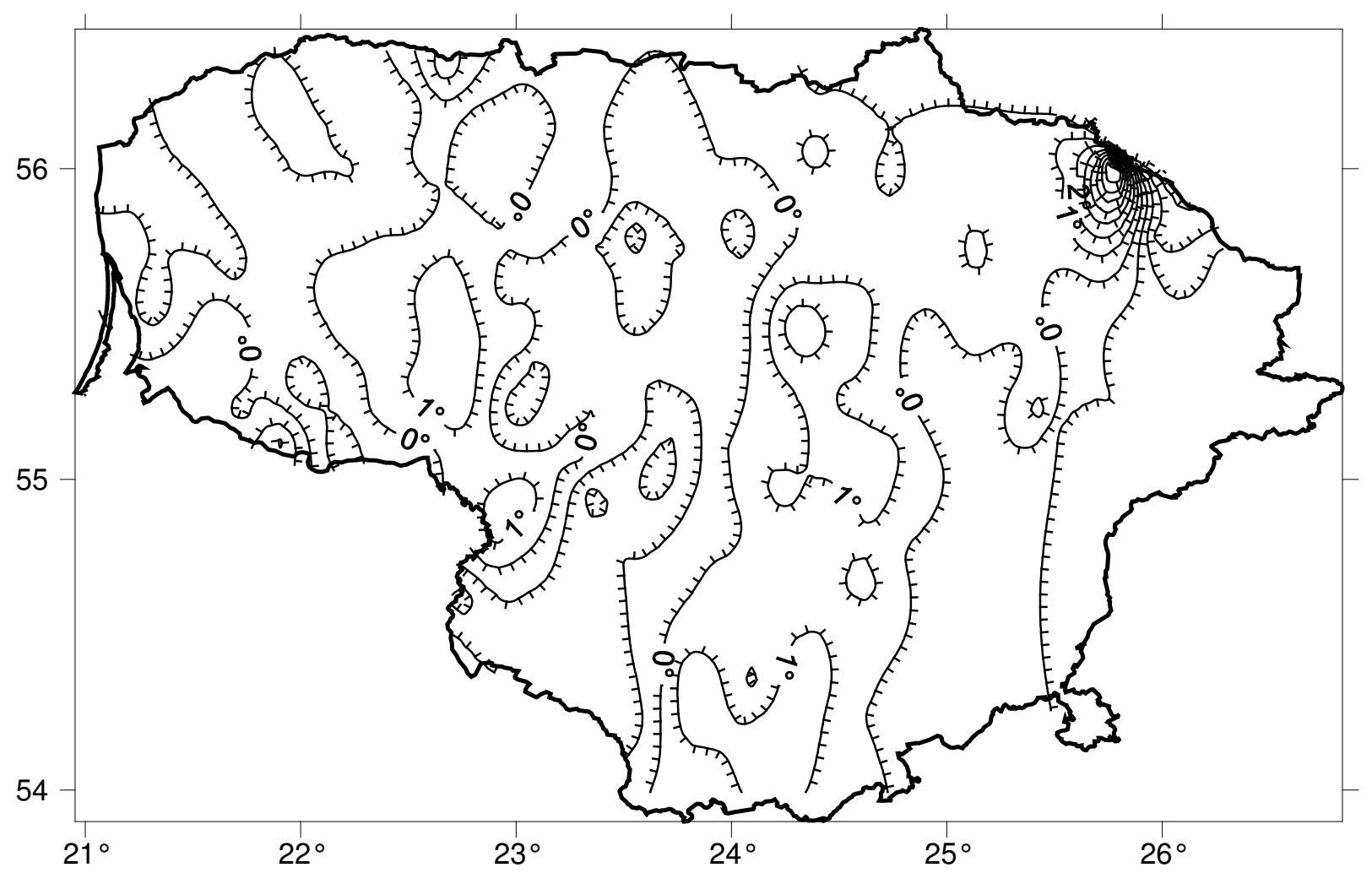

Fig 3. Map of differences between updated map by K. Sleževičius for epoch 2000.5 and the WMM

\section{Conclusions}

1. Magnetic declination values at the stations of geomagnetic field research vary from $4^{\circ} 04^{\prime} 51^{\prime \prime}$ to 626'54".

2. Based on the geomagnetic field parameters and observational data from 1999.5-2001.5 and 2001.52004.5, annual variations were estimated. The largest annual variations in declination reached 6' 37" (at the station in Tryškiai). Annual variations in declination decreased in southern Lithuania in 2001.5-2004.5 compared to 1999.5-2001.5 and increased in the northern part of the country.

3. The accuracy of the world magnetic model in Lithuania was tested for the first time. Within most of the country, the errors of the model reach $1.5^{\circ}$, but in the northeast of the country, they rise to $4^{\circ}$. The errors of the model at repeat stations and at airports can reach $2^{\circ}$.

4. Research of the suitability of geomagnetic observatories for the reduction of the data collected from geomagnetic observations was conducted. Based on this research, the Belsk Geomagnetic Observatory was determined to be the one best suited for the reduction of Lithuanian observation data.

5. To determine astronomic meridian direction from Sun hour angle and to reduce the effect of all errors, it is important to determine allowable coefficient $K$ values by taking into account the desirable accuracy of the Sun's azimuth and error of hour angle. These values describe the most suitable position of the Sun for observations. Zenith distance of Sun should be below $80^{\circ}$. Selecting the Sun's position symmetrically on the sides of the meridian could reduce the effect of latitude and errors in the Sun's declination. The accuracy of the direction of the astronomic meridian can be improved by applying this method; the accuracy of magnetic declination will therefore improve as well.

\section{References}

1. Daly, L.; le Goff, M. 1996. An updated and homogeneous world secular variation database: smoothing of the archaeomagnetic results. Physics of the Earth and Planetary Interiors, 93: 159-190.

2. Hongre, L.; Hulot, G; Khokhlov, A. 1998. An analysis of the geomagnetic field over the past 2000 years. Physics of the Earth and Planetary Interiors, 106: 311-335.

3. Kowalik, B.; Obuchovski R. 2005. Investigation of geomagnetic field on the Lithuanian territory. In The 6th International Conference "Environmental Engineering”, Selected Papers. Vilnius: Technika, 2, 908-912.

4. Lanza, R.; Meloni, A. 2006. The Earth's magnetism. An Introduction for Geologists, Springer, 12: 278.

5. Newitt, L. R.; Barton, C. E.; Bitterly, J. 1996. Guide for magnetic repeat station surveys. In IAGA, published by Secretary-General of IAGA, WGV-8, NOAA space Environment Center, Boulder, CO 80303-3328, USA. Warsaw, 8-112.

6. Obuchovski, R. 2004. Research on WMM-00 Geomagnetic field model accuracy in Lithuania. Geodesy and Cartography, 30 (1): 14-21.

7. Petroškevičius, P.; Obuchovski, R. 2006. Investigation of possibilities for astronomical 
meridian determination by the hour angle of the Sun. Geodesy and Cartography, 32(1): 23-28.

8. Sas-Uhrynowski, A.; Mroczek, S.; Abromavičius et al. 1998. Investigations of the magnetic field over the territory of Lithuania. Geodesy and Cartography, 28(3): 88-94.

\section{MAGNETINĖS DEKLINACIJOS LIETUVOS TERITORIJOJE TYRIMAI}

R. Obuchovski, P. Petroškevičius, A. Būga

S a n tra k a

Magnetinės deklinacijos reikšmė navigacijoje dažniausiai apskaičiuojama naudojant pasaulini magnetinị modeli WMM (World Magnetic Model). Lietuvoje be pakartotinų geomagnetinio lauko matavimų amžių variacijų punktuose magnetinès deklinacijos reikšmè išmatuota ir keturiuose Lietuvos oro uostuose. Straipsnyje ivertintas pasaulinio geomagnetinio lauko modelio WMM tikslumas Lietuvos teritorijoje. Tirta ir ivertinta geomagnetinio lauko parametrų kaita. Išanalizuotas aplinkinių observatorijų tinkamumas Lietuvoje atliktų matavimų rezultatų redukavimui. Remiantis gautais tyrimų rezultatais, galima pasirinkti tinkamiausią laiką krypties astronominiam azimutui, o kartu ir astronominio dienovidinio krypčiai nustatyti, atsižvelgiant i žinomas parametrų paklaidas, punkto platumą ir metų laiką.

Reikšminiai žodžiai: magnetinė deklinacija, astronominis azimutas, geomagnetinio lauko modelis.
9. Sleževičius, K.; Saldukas, I. 1941. Magnetic map of Lithuania composed in 1936-1938. Vilnius: Faculty of Mathematics-Natural Sciences of Vilnius University. 5-52. 